\title{
Relationship Marketing and Customer Loyalty: Do Customer Satisfaction and Customer Trust Really Serve as Intervening Variables?
}

\author{
Mohamad Rizan $^{1}$, Ari Warokka ${ }^{2}$ and Dewi Listyawati ${ }^{3}$ \\ ${ }^{1}$ Faculty of Economics, State University of Jakarta, Indonesia \\ ${ }^{2}$ State University of Jakarta, Indonesia and \\ Centro Internacional "Carlos V", Universidad Autonoma de Madrid, Spain \\ ${ }^{3}$ Business Practitioner, Jakarta, Indonesia
}

Correspondence should be addressed to: Ari Warokka; ari.warokka@yahoo.com

Received date: 7 July 2013; Accepted date: 6 Mach 2014; Published date: 28 October 2014

Academic Editor: Hamsatulazura binti Hamzah

Copyright (C) 2014. Mohamad Rizan, Ari Warokka and Dewi Listyawati. Distributed under Creative Commons CC-BY 3.0

\begin{abstract}
To contend the traditional transaction marketing, which focuses on the completion of the transaction and the pursuit of maximizing profits for each transaction, the relationship marketing in the banking sector, on the other hand, offers the establishment of strong relationships and stable partnerships between the bank and its customer in order to maximize the pursuit of the interests of all aspects of the relationship. This paper examined the nature of linkages between relationship marketing and customer loyalty by using customer satisfaction and customer trust as the intervening variables. It investigated the customer perception on customer satisfaction's characteristics and confidence in exchange partner's reliability and integrity as the mediating factors to build their trust on the banking services. The researchers employed 150 respondents of private banking as the sample. This paper used Structural Equation Modeling (SEM) to analysis the relationship. The results revealed that the relationship marketing tactics affected customer loyalty significantly through customer trust and customer satisfaction. It explicitly demonstrates that the banks have undertaken an organization-wide strategy to manage and nurture their interaction with clients and sales prospects as the base for their customer loyalty.
\end{abstract}

Keywords: relational marketing, customer satisfaction, customer trust, customer loyalti

Cite this Article as: Mohamad Rizan, Ari Warokka and Dewi Listyawati (2014), "Relationship Marketing and Customer Loyalty: Do Customer Satisfaction and Customer Trust Really Serve as Intervening Variables? ", Journal of Marketing Research and Case Studies, Vol. 2014 (2014), Article ID 724178, 


\section{Introduction}

The shift in the marketing paradigm (Gronroos, 1997), as a result of globalization of businesses and the evolving recognition of the importance of customer retention, customer loyalty, market economies and customer relationship economies, has brought companies to deliver the benefits that accrue to customers. The global financial crisis has left bankers searching for a profitable path forward in a permanently altered competitive landscape. It becomes worsened with the sunk-public trust in financial-services companies, underscoring the need for retail bankers to repair badly damaged customer relationships. Therefore, Bose (2002) reports that it is becoming evident that companies have to modify fundamentally the way in which marketing is done, i.e. a shift from managing a big pool of clients to managing a specific customer base. This modification includes establishing, maintaining and enhancing relationships for the sake of building up long-term relationships with customers so that the economic goals are achieved. This effort is also to answer the fact that it has been the practice by companies to devote greater attention and marketing effort to attracting new customers rather than retaining existing ones (Kotler, 2000).

The transactional marketing, which is the old-fashioned paradigm, used to emphasize the concepts of 4Ps that focused only on attracting businesses, but not so much on customer retention (Gummesson, 1999). Prior studies in relationship marketing (Kotler, 2001; Doyle, 2000; Piercy, 2002) confirm that retaining the companies' existing-customers is more profitable than attracting new one. As a result, the concept of relationship marketing was developed on the basis that customers vary in their needs, preferences, buying behavior and price sensitivity. Besides, relationship marketing also helps to increase market share, profitability and reduce the cost (Reichheld, 1993).

Based on this growing concept, in this study, the researchers would like to examine why relationship marketing is becoming a more important marketing strategy than others in business environment, especially in financial services. In the increasingly competitive global monetary world, relationship marketing has been advocated as an excellent way for banks to establish a unique long-term relationship with their customers. The quick pace of developing technologies has intensified the competition and made it difficult to gain strategic advantage through physical products alone. At the same time, customers are more demanding; they not only expect excellent high-quality goods, but they also expect high level of service available with them as the requirement for their loyalty to the banks. Meanwhile, most of the core products/services in commercial banking are fairly generic, and it is difficult for most of this kind of financial institution to compete purely on this core service. Consequently, banks use the relationship marketing concept as a strategy to build loyalty with each customer, which leads to improved financial and market performance, and an increased competitive edge (Ravesteyn, 2005).

Our study will provide some important contributions, such as a testing of the two types of the relationship marketing's influence on customer loyalty, i.e. direct and indirect powers, and experimenting on the retention strategies and tactics used by Indonesian banks to build relationships and make the customers loyal to the banks through customer satisfaction and customer trust. It will also expand the implementation of relationship marketing in emerging Southeast Asian banking industry. In this study, we will test specifically the intervening effects of customer satisfaction and customer trust in the nexus between the relationship marketing and customer loyalty. The expected empirical findings of this study will be valuable information to set and update the current marketing approach to increase customers' closed-engagement to their bank. The satisfied customers, whose high trust on their bank, as reported in many studies, tend to deal with more 
businesses and transactions than the unsatisfied ones do.

To present the empirical findings, the paper is organized as follows. The literature review and prior studies on relationship marketing, customer satisfaction, customer trust, and customer loyalty are briefly outlined in Section 2 . The methodology and research model is described in Section 3, followed by the research results and discussion in Section 4. We provide some concluding remarks in Section 5.

\section{Literature Review}

The recognition of the importance of relationship marketing has forced the Indonesian banking sector to strive gaining a competitive advantage right in the local market by keeping improving the system as a whole and the quality of services, specifically. The Indonesian banks, with their largest asset base within Indonesia's domestic economy and widely considered as the country's economic driver, are finding that they need to focus on service to keep up with the rising customer expectations and to compete effectively (Mulyaningsih and Daly, 2011).

According to the Report of Customer Loyalty in Retail Banking (Bain, 2013), Indonesian banking customers are the second top switchers in forming new primary relationships with banks. It means that their loyalty depend on the ways of banks in meeting the customers' needs and wants. The Report of Banking Competition in 2013 (MarkPlus Insight, 2013) affirms that banks should change their way in attracting customers and building a more solid level of customer loyalty in order to gain higher profit, especially for corporates and commercial customers. The report reveals that the tendency of having more than one active saving account, or even credit card, has become a common trend among customers in the last couple of years. This phenomenon itself is a strong indication that customers nowadays tend to be disloyal and no longer want to be dependent on one bank only. Furthermore, the report views that the transactional attributes, i.e. the ease and convenience that customers experience when they deposit their money or do other routine transactions, indeed have bigger impacts on loyalty.

To respond to these increasing competitive pressures in the business environment, banks are aggressive toward attracting customers and getting to know them in order to meet better their customers' needs, offer them new range of products/services, and strive to set up long-term relationships with them. Banks have considered this relationship as the backbone of their business activities and marketing (O'Malley and Tynan, 2000; Sheth and Pavatiyar, 2000; 0'Malley, 2003). It is because a large part of banks' revenues is received from interest margins; therefore, customers' volume of business has a major impact on profitability. If relationship costs are minimized and relationship revenue is maximized over time, satisfied and loyal customers should generate greater profitability than shortterm customers.

\section{Relationship Marketing and Customer Loyalty}

The basic philosophies of relationship marketing are based on the assumption that company-customer interactions and strategies can earn and keep the loyalty of customers (Berry, 1995). Gummesson (1999) defines relationship marketing as a continuation of the mutual relationship between a service provider and a customer who will lead to formation of profitability. Therefore, banks, as the financial service providers, can retain profitable customers and increase their loyalty by planning in their marketing strategies (Kim, Park, \& Jeong, 2004). Prior studies confirm that service companies have received incredible benefits of loyal customers (Bagherzad, Chavosh, and Hosseinikhah, 2011). Moorman, Zaltman, and Deshpandé (1992) stated that customer loyalty was an intention to keep a valued relationship. Yim, David and Chan (2008) defined customer loyalty as a highly deep commitment to keep on purchasing a product or service in the future regardless 
of the fact that there are situational factors and marketing efforts, which have been potential to create switching behavior. In the banking sector, it is the main job of manager and marketers to create and develop customer loyalty if they want to maintain their company and increase its profitability. Therefore, we hypothesize the association between relationship marketing and customer loyalty as follows:

H1: Relationship marketing influences customer loyalty.

\section{Relationship Marketing and Customer Satisfaction}

Doyle (2002) argues that the three cornerstones of relationship marketing are: planning and controlling of customer satisfaction, building and maintaining stable relationships (customer loyalty) and customer value management. Kotler (200) argues that customer satisfaction management includes the comparison between the expected delivered value and the real delivered-value as well as the image of the company, the readiness to reaction, the dependability and the product attributes. Furthermore, Kotler, Armstrong, Saunders, and Wong (2001) conclude that customer satisfaction is completely dependent of the customer expectation and how the customer's actual perception of the product's performance matches the expectations. The customer will be satisfied if the performance matches or exceeds the expectations, and in contrary, the customer will be dissatisfied if the performance falls short of the expectation. Prior studies reveal that relationship programs enhance the flow of information between the bank and customers and increase customers' positive feelings towards their bank. Thus, it will increase the customer satisfaction and relationship strength of the banks (Barnes and Howlett, 1998; Ennew and Binks, 1996). Therefore, based on those empirical findings, hypothesis 2 is proposed as below:

H2: Relationship marketing tactics influence customer satisfaction.

\section{Relationship Marketing and Customer Trust}

The final concept necessary to build relationships is trust. In business, trust refers to the confidence that one partner, the customer, has in the business's reliability and integrity to deliver goods and services (Proctor, 2000). Trust relates to the belief that a customer has in an honest investment and engagement with the service provider (Peltier, Pointer, and Schibrowsky, 2006). In the banking context, trust is defined as customer confidence in the quality and reliability of the services offered by the organization (Garbarino and Johnson, 1999). It becomes the moral values that are established to enhance their business relationship between banks and customers. Dwyer, Schurr, and Oh (1987) argue that trust is considered the foundation of strategic partnerships, and it seems to be a mediating or intermediary element in provider-customer relationships. Prior studies find trust to be the core of the relational approach and consider it key to the development of the notion of commitment in provider-user relationships (Gundlach and Murphy, 1993; Nooteboom et al., 1998; Tax et al., 1998; Ratnasingam and Phan, 2003). According to Urban, Sultan, and Qualls (2000), trust is also considered as a key element in establishing long-term relationships with customers and in maintaining a company's market share. Therefore, based on the prior empirical findings, hypothesis 3 is proposed as below:

H3: Relationship marketing tactics affect customer trust.

\section{Customer Satisfaction, Customer Trust and Customer Loyalty}

Customer satisfaction is important because satisfied customers are less likely to switch to a competitor (Kotler, 2001). Customer loyalty and the ability to retain customers are, therefore, highly dependent on the customer's actual satisfaction; undoubtedly, customer service is a key ingredient in relationship marketing and consequently, in customer retention (Sheth 
and Parvatiyar, 1995; Gummeson, 1997; Khalifa, Limayem, and Liu, 2002; Doyle, 2002). Customers in successful relationships have been far more potential for loyalty as they are often prepared to pay a premium price for goods or services (Newell, 2000). According to Doyle (2002), a highly satisfied customer will exhibit the following characteristics: (1) stays in loyal longer, (2) buys more, (3) talks favorably about the company, (4) pays less attention to competing brands and advertising, and (5) the company will cost less to serve than new customers. The study of Flint, Blocker and Boutin (2011) shows the customer loyalty is derived when organizations give more importance to the expectations of its customers. Prior studies confirm that customer satisfaction and loyalty are highly correlated (Athanassopoulos, Gounaris, and Strathakopoulos, 2001; Hallowell, 1996; Silvestro and Cross, 2000). Based on those empirical findings, we proposed the following hypothesis:
H4: Customer satisfaction influences customer loyalty.

According to the study of Coulter and Coulter (2003), more than half of bank customers believe that having a relationship of trust with their financial institution is more important than getting the best value for money. It means that when the customers have trust on the services and products of a company, then it will lead them towards loyalty (Ribbink, Liljander, and Streukens, 2004). Even though there are several factors that determine customer loyalty, the role of trust is a crucial one (Harris and Goode, 2004). It affirms that customer loyalty begins with trust. Based on those prior findings, we hypothesize the relation between customer trust and customer loyalty as follows:

H5: Customer trust affects customer loyalty.

We summarize all proposed hypotheses as seen in Table 1.

Table 1: Summary of Hypotheses

\begin{tabular}{|l|l|}
\hline Hypothesis $\mathbf{1}$ & Relationship marketing influences customer loyalty \\
\hline Hypothesis $\mathbf{2}$ & Relationship marketing tactics influence customer satisfaction \\
\hline Hypothesis $\mathbf{3}$ & Relationship marketing tactics affect customer trust \\
\hline Hypothesis $\mathbf{4}$ & Customer satisfaction influences customer loyalty \\
\hline Hypothesis $\mathbf{5}$ & Customer trust affects customer loyalty \\
\hline
\end{tabular}

Therefore, we model the hypotheses testing in the following research framework:

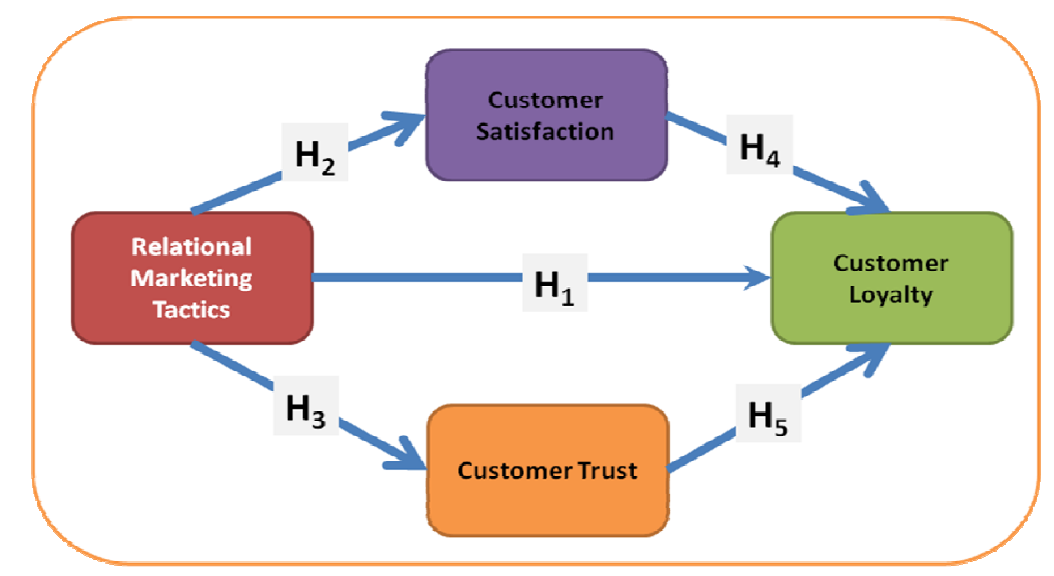

Figure 1: Research Model of Relationship Marketing and Customer Loyalty 
This study is different from prior studies in terms of providing the effect of relationship marketing tactics on customer's trust, satisfaction and loyalty in the context of emerging markets. Specifically, it tests customer satisfaction and customer trust as the intervening variables in the linkage of relationship marketing and customer loyalty. It becomes important since the Indonesian banking industry has already passed a difficult time of scandalous events that erode customer's positive perception on bank's good governance. The results will provide valuable and recent information on the relationship marketing tactics that marketers can use to form the bank image.

\section{Methodology and Research Model}

To study the linkage between relationship marketing and customer loyalty, we used 150 bank customers as the sample, which has certain characteristics, such as his or her minimum age is 17 years old, have been the customer at least for one year, and have made more than six times banking transactions within the last six months. We argued that respondents with those characteristics could evaluate the marketing tactics developed by the banks. We employed personal interviews using questionnaires as a measurement tool to collect the data, and which were conducted during the period January to May 2012.To support the primary data, we also explored the documented data on the customer surveys done by the banks.

In this study, to measure marketing relational tactics, we adapt the work of Yen, Liu, and Chao (2009), which has three dimensions, i.e. preferential treatment, interpersonal communication, and tangible rewards. These dimensions are measured in eight indicators. Meanwhile, to measure customer loyalty, we adopt the work of
Zeithaml and Bitner (2003), which has four dimensions, i.e. service quality, product quality, price, and situational factors. These dimensions are quantified in 10 indicators. We implemented the work of Morgan and Hunt (1994) to gauge customer trust, which used two dimensions, i.e. confidence in exchange partner's reliability and integrity. Both dimensions are operationalized in six indicators. To measure customer loyalty, we used the Griffin's four dimensions of customer loyalty (2009), i.e. buy regularly, buy a cross-section of product or services, refer others, and immune to the pull of the competition. All indicators are measured. A five-point Likert scale is used, ranging from "strongly disagree" (1) to "vigorously agree" (5).

To examine the hypotheses, we used Structural Equation Model (SEM). Before using SEM, we tested the reliability and validity of the indicators/constructs.. We used the corrected item-total correlation method to study the constructs' validity. For relational marketing tactics' constructs, all items have values more than 0.361 (the table value for $\mathrm{df}=28, \alpha \leq 0.05$ ). It means that items used to measure relational marketing tactics are valid. The indicators' values of customer satisfaction, customer trust, and customer loyalty are also more than the table value (0.361). Meanwhile; the values of Cronbach's alpha for relational marketing tactics, customer satisfaction, customer trust, and customer loyalty are $0.913,0.918,0.900$, and 0.943 , respectively. Therefore, it can be said that all constructs used in this study are valid and reliable.

The measurement model indices reveal that the proposed model is fit and parsimony (Table 2). 
Table 2: Fit Indices for the Measurement Model of the Relationship between Relational Marketing Tactics and Customer Loyalty

\begin{tabular}{|l|c|c|c|}
\hline Fit Index & This Study & Recommended values & Source \\
\hline df & 57 & & \\
\hline$\chi^{2}$ & 64.78 & & Gefen (2000) \\
\hline $\boldsymbol{\chi}^{2} / \mathbf{d f}$ & 1.136 & $\leq 3.00$ & Hoyle (1995) \\
\hline GFI & 0.940 & $\geq 0.90$ & Chau and Hu (2001) \\
\hline AGFI & 0.900 & $\geq 0.80$ & Bagozzi and Yi (1988) \\
\hline CFI & 0.990 & $\geq 0.90$ & Browne and Cudeck (1993) \\
\hline RMSEA & 0.030 & $\leq 0.08$ & Bagozzi and Yi (1988) \\
\hline NNFI (TLI) & 0.990 & $\geq 0.90$ &
\end{tabular}

Thus, all variables can be measured in the proposed model. The results can be viewed in Figure 2.

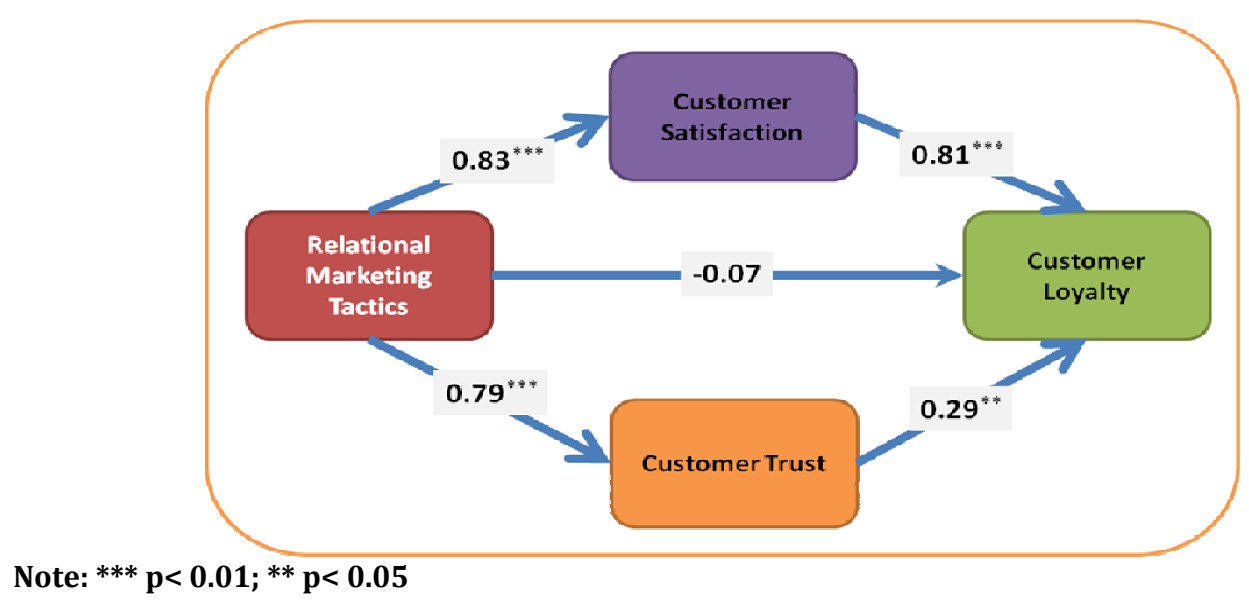

\section{Research Results and Discussion}

In this study, the result of first hypothesis testing reveals that relational marketing tactics do not influence customer loyalty $(\beta$ $=-0.07, p<0.05)$. This finding is contrary to the work of Guenzi and Pelloni (2004) and Ndubisi, Chan, and Gibson (2007) in which relational marketing tactics and interpersonal relationship affect directly customer loyalty. We argue that the samples, who are prime (affluent) customers in majority, are not influenced by relational marketing tactics due to the fact that their chief objective in saving the money in the bank is for investment diversification purpose. The main concern is to get high return, not additional or privileged services. The current marketing tactics do not influence directly this customer segment's loyalty. The report of Bain \& Co. (2010) revealed that banks were rated poorly with their most affluent customers. Among US banks, respondents from households with investable assets of \$1 million or more (affluent households) gave Net Promoter Scores (NPS) averaging just 2 percent (versus 16 percent from those with less assets).

The results demonstrate that relational marketing tactics influence significantly customer satisfaction and customer trust $(\beta=0.83, p<0.01$ and $\beta=0.79, p<0.01$, respectively). It supports prior studies of De Wulf (2001), Yen et al. (2009), Guenzi and Pelloni (2004), and Wang, Chiung, and Yung (2006). The customers perceived 
positively the bank's marketing tactics, and they were satisfied by the services given. At the same time, these tactics also affect significantly customer trust. It means that the tactics increased the customers' trust for the bank. This finding is in line with the work of Morgan and Hunt (1994), which reports that it is important to get customer trust. According to Morgan and Hunt (1994), trust is the willingness to rely on an exchange partner in whom one has confidence. Therefore, a bank in which a client has confidence definitely stands ahead of competition. They argue that the bank's profitability, growth, market share, and customer retention are the results of highly customer trust in that bank. Consequently, to gain a strategic advantage and survive in today's increasingly competitive environment, the banks should employ innovative relational marketing tactics to get trust from its customer.

The results of fourth and fifth hypotheses testing revealed that customer satisfaction and customer trust affect significantly customer loyalty $(\beta=0.81, \mathrm{p}<0.01$ and $\beta=$ $0.29, \mathrm{p}<0.05$, respectively). These findings are in line with the studies of Singh and Sirdesmukh (2000), Chiou and Droge (2006), Bowen and Chen (2001), Guenzi and Pelloni (2004), Ball, Coelho, and Machas (2004). The satisfied customers are positively becoming loyal customers. The same thing will happen for the companies have successfully gotten trust from their customers. The loyal customers will guarantee the company's sustainability life. As demonstrated in prior findings, for bank customers, having a relationship of trust with their financial institution is more important than getting the best value for money (Coulter and Coulter, 2003). In other words, trustworthiness is the key of any kind of businesses. It may seem obvious, but since the study shows that customer satisfaction and trust are the key drivers of customer loyalty, subsequently the key message for the banks is to get their service right, meet the very essential customer need, use active listening then act upon it, manage the corporate brand reputation effectively, and use social networks better. By meeting these basic requirements optimally, the company could expect their customer satisfaction and trust that lead to customer loyalty.

This study also provides significant evidence on the role of customer satisfaction and trust as the intervening variables. The indirect influence of relational marketing tactics on customer loyalty through customer satisfaction is $67 \%(0.83 \times 0.81)$, and through customer's trust is $23 \%(0.79 \times 0.29)$. These not-direct effects are greater than the direct one, i.e. $7 \%$. In the context of retail bank industry, affluent (prime) customers are not easily influenced by the marketing tactics. Their special position (wealthy customer segment) requires specific treatments due to the fact that normal relational marketing tactics could not influence their loyalty directly. It is not easy for retail banks to carve out an equivalent high-end service offering for wealthy account holders as given by private banks and assetmanagement firms that cater for the affluent high-net-worth clients. However, for retail banks, continuous and effective tactics could generate loyalty through customer satisfaction and trust.

This study proves that to build successful long-term partnerships, customers look for a bank that is more than a normal bank, a partner who is also interested in their general well-being than purely in what can be sold to them. Loyal customers stay longer with banks that treat them well. The facts show that today customers have become more knowledgeable, sophisticated and assertive, with an increasing demand for tailor-made and innovative products and services. They are no longer interested in buying off-the-shelf solutions, but demand remedies that fit their business models and plans. Therefore, to ensure they are steadily ready, it is crucial for banks to have strong relationships with their evolving customers. It is because investing in loyalty can generate more attractive returns than rolling out an ambitious new marketing plan or building additional branches.

It implies that to create a loyalty system, the banks should impose a set of attitudes and behaviors deeply embedded in the 
metabolism of the organization. This system needs to engage employees by instilling loyalty disciplines. To run the relational marketing tactics, it needs qualified employees. Bain (2010) suggests four things. First, the banks should develop training programs to introduce and reinforce customer loyalty. It is important that employees understand what service skills they need to bring to the job to earn a top score of 10. Second, managers and supervisors need to provide ongoing, realtime feedback and coaching on their customer-service skills. Third, employee engagement should be built in a work environment grounded in openness and trust. The organization needs to create forums and communication channels that allow employees' voices to be heard. Finally, employees need to be inspired to continue to lift their performance. Positive customer feedback and testimonials from satisfied customers provide countless stories to celebrate and share throughout the organization.

\section{Conclusion}

This paper examines the relationship of relational marketing tactics and customer loyalty in retail banks. By using customer satisfaction and customer trust as the intervening variables, this study confirms that customer-relationship-centered marketing tactics influence directly customer loyalty. The combined-indirectly effects of relational marketing tactics on customer loyalty through customer satisfaction and trust are greater than the straight one. We argue that the sample characteristic, i.e. affluent (prime) customers, is the cause of the insignificant direct effect of bank's marketing tactics on customer loyalty.

This study reaffirms the importance of customer loyalty. In banking industry, customer loyalty not only makes a plat form where the customer is ready to stay maximum time with the organization and causes long-term benefit, but also provides a name of inspiration with the company products or services. It is important to banks to optimize the technology usage, both in the way that banks analyze customer data internally and the way they communicate information to their customers. When analyzing client activity, banks could use the technology to predict the trends rather than simple shifts in volumes. By applying smart systems, which automatically generate market news on customer financial performance and new ventures, banks could generate possible avenues for new banking solutions. Therefore, banks should create and use customer reporting as a result of a focus on relationship marketing.

We believe that for most retail banks, the best competitive way forward should be organic growth rooted in strong customer relationships and the economic rewards they deliver. The most effective banks, like any organization that systematically sets out to convert customers into advocates, should put customer loyalty at the heart of their growth strategies. Banks need to provide a service that goes well beyond the ordinary to reap the truly attractive rewards that come to those that understand, relentlessly pursue and merit the loyalty of the most attractive customer segments.

\section{References}

1. Athanassopoulos, A., Gounaris, S. and Strathakopoulos, V. (2001), 'Behavioural Responses to Customer Satisfaction: An Empirical Study,' European Journal of Marketing, 35(5/6), 687-707.

2. Bagherzad, A, Chavosh, A. and Hosseinikhah, S. (2011), 'The Influence of Relationship Marketing Tactics on Customer's Loyalty in B2C RelationshipThe Role of Communication and Personalization,' European Journal of Economics, Finance and Administrative Sciences, 5(31), 49-56.

3. Bain \& Co. Inc. (2010), 'Customer Loyalty in Retail Banking: North America 2010,' Boston: Bain \& Co. Inc.

4. Bain \& Co. Inc. (2013), 'Customer Loyalty in Retail Banking: Global Edition 2013,' Boston: Bain \& Co. Inc. 
5. Ball, D., Coelho, PS. and Machas, A. (2004), 'The Role of Communication and Trust in Explaining Customer Loyalty,' European Journal of Marketing, 38(9), 1272-1293.

6. Barnes, JG. and Howlett, DM. (1998), 'Predictors of Equity in Relationships Between Financial Services Providers and Retail Customers,' International Journal of Bank Marketing, 16(1), 15-23.

7. Bowen, JT. and Chen, SL. (2001), 'The Relationship Between Customer Loyalty and Customer Satisfaction,' International Journal of Hospitality Management, 13(5), 213-217.

8. Chiou, JS and Dronge, C. (2006), 'Service Quality, Trust, Specific Asset Investment and Expertise, Direct and Indirect Effects in a Satisfaction-Loyalty Framework,' Academy of Marketing Science, 34(16), 613-627.

9. Coulter, KS. and Coulter, RA. (2003), 'The Effects of Industry Knowledge on the Development of Trust in Service Relationships,' International Journal of Research in Marketing, 20(1), 31-43.

10. De Wulf, K., Schroder, GO. and Iacobucci, D. (2001), 'Investments in Consumer Relationships: A Cross-Country and Cross-Industry Exploration,' Journal of Marketing 65(4), 33-50.

11. Doyle, P. (2002), 'Marketing Management and Strategy,' 3rd ed. London: Prentice Hall International.

12. Dwyer, FR., Schurr, PH. and Oh, S. (1987), 'Developing Buyer-Seller Relationship,' Journal of Marketing, 51(2), 11-27.

13. Ennew, CT. and Binks, MR. (1999), 'Impact of Participative Service Relationships on Quality, Satisfaction and Retention: An Exploratory Study,' Journal of Business Research, 46(2), 121-132.

14. Garbarino, E. and Johnson, M. (1999), 'The Different Roles of Satisfaction, Trust and Commitment in Customer
Relationships,' Journal of Marketing, 63(2), 70-87.

15. Grönroos, C. (1990), 'Relationship Approach to the Marketing Function in Service Contexts: The Marketing and Organizational Behaviour Interface,' Journal of Business Research, 20 (1), 3-12

16. Gronroos, C. (1994), 'From Marketing Mix to Relationship Marketing: Towards a Paradigm Shift in Marketing,' Management Decision, 32(2), 4-20

17. Gronroos, C. (1996), 'Relationship Marketing: Strategic and Tactical Implications,' Management Decision, 32, (2), 4-20.

18. Guenzi, P. and Pelloni, O. (2004), 'The Impact of Interpersonal Relationships on Customer Satisfaction and Loyalty to the Service Provider,' International Journal of Service Industry Management, 15(4), 365384.

19. Gundlach, GT. and Murphy, PE. (1993), 'Ethical and Legal Foundations of Relational Marketing Exchanges,' Journal of Marketing, 57(4), 35-47.

20. Gummesson, E. (1987), 'The New Marketing - Developing Long-Term Interactive Relationships,' Long Range Planning, 20(4), 10-20

21. Gummesson, E. (1999), 'Total Relationship Marketing - Rethinking Marketing Management: From 4PS To 30S,' Butterworth: Heinermann.

22. Hallowell, R. (1996), 'The Relationships of Customer Satisfaction, Customer Loyalty, and Profitability: An Empirical Study,' International Journal of Service Industry Management, 7(4), 27-42.

23. Khalifa, M., Limayem, M., and Liu, V. (2002), 'Online Customer Stickiness: A Longitudinal Study,' Journal of Global Information Management, 10(3), 57-68

24. Kotler, P., Armstrong G., Saunders, J. and Wong, V. (2001), 'Principles of Marketing,' Harlow: Prentice Hall Europe. 
25. Kotler, P. (2000), 'Marketing Management,' New Jersey: Upper Saddle River.

26. MarkPlus Insight. (2013), 'Banking Competition in 2013: In the time of Regulatory Transition,' Jakarta: MarkPlus Consulting.

27. Morgan, RM. and Hunt, SD. (1994), 'The Commitment-Trust Theory of Relationship Marketing,' Journal of Marketing, 58(3), 2038.

28. Moorman, C., Zaltman, G. and Deshpandé, R. (1992), 'Relationships between Providers and Users of Market Research: The Dynamics of Trust within and between Organizations,' Journal of Marketing Research, 29 (3), 314-329.

29. Mulyaningsih, T. and Daly, A. (2011), 'Competitive Conditions in Banking Industry: An Empirical Analysis of the Consolidation, Competition and Concentration in the Indonesia Banking Industry between 2001 and 2009,' Bulletin of Monetary Economics and Banking, 14(2), 141-176.

30. Ndubisi, NO., Chan, KW. and Gibson, CN. (2007), 'Supplier-Customer Relationship Management and Customer Loyalty: The Banking Industry Perspective,' Journal of Enterprise Information Management, 20(2):222-236.

31. Nooteboom, B., Berger, H. and Noorderhaven, NG. (1997), 'Effects of Trust and Governance on Relational Risk,' Academy of Management Journal, 40(2), 308-339.

32. O'Malley, L. and Tynan, C. (2000), 'Relationship Marketing in Consumer Markets. Rhetoric or Reality?' European Journal of Marketing, 34(7), 797-815.

33. Peltier, JW., Pointer, L., and Schibrowsky, JA. (2006), Internal Marketing and the Antecedents of Nurse Satisfaction and Loyalty,' Health Marketing Quarterly, 23(4), 75-108.
34. Proctor, T. (2000), 'Strategic Marketing: An Introduction,' London: Routledge.

35. Ratnasingam, P. and Phan, DD. (2003), 'Trading Partner Trust in B2B ECommerce: A Case Study,' Information Systems Management, 20(3), 39-50.

36. Ravesteyn, J.V. (2005), 'The Effect of Relationship Banking on Customer Loyalty in the Retail Business Banking Industry,' Thesis, Graduate School of Business Leadership, University of South Africa.

37. Sheth, JN. and Parvatiyar, A. (2000), 'The Evolution of Relationship Marketing,' In Sheth, JN. and Parvatiyar, A. (eds), Handbook of Relationship Marketing. Thousand Oaks/London/New Delhi: Sage

38. Silvestro, R. and Cross, S. (2000), 'Applying the Service Profit Chain in a Retail Environment: Challenging the 'Satisfaction Mirror', International Journal of Service Industry Management, 11(3), 244-268.

39. Singh, J. and Sirdeshmukh, D. (2000), 'Agency and Trust Mechanisms in Consumer Satisfaction and Loyalty Judgments,' Journal of the Academy of Marketing Science, 28(1), 150-167.

40. Tax, SS., Brown, SW. and Chandrashekaran, M. (1998), 'Customer Evaluations of Service Complaint Experiences: Implications for Relationship Marketing,' Journal of Marketing, 62(2), 6077.

41. Urban, G., Sultan, F. and Qualls, W. (2000), 'Placing Trust at the Center of Your Internet Strategy,' Sloan Management Review, 42(1), 39-48.

42. Wang, WH, Chiung, JL., and Yung, DW. (2006), 'Relationship Bonding Tactics, Relationship Quality and Customer Behavioral Loyalty - Behavioral Sequence in Taiwan's Information Services Industry,' Journal of Services Research, 6(1), 31-57.

43. Yen, TF., Liu, HJ., and Chao, LT. (2009), 'Managing Relationship Efforts to Influence 
Loyalty: An Empirical Study on the Sun Link Sea Forest and Recreational Park, Taiwan,' The International Journal of Organizational Innovation, 2(1), 179-194.

44. Yim, CK, David K. and Chan, KW. (2008), Strengthening Customer Loyalty through Intimacy and Passion: Roles of Customer-Firm Affection and Customer-
Staff Relationships in Services,' Journal of Marketing Research, 45 (6), 741- 756.

45. Zeithaml, VA. and Bitner, MJ. (2003), 'Service Marketing: Integrating Customer Focus Across the Firm,' 3rd Edition. New York: Irwin McGraw-Hill. 